\title{
Thermosensitive cell growth mutants of Enterococcus hirae that elongate at non-permissive temperature are stimulated to divide by parental autolytic enzymes
}

\author{
Maria del Mar Lleò, ${ }^{1 *}$ Pietro Canepari ${ }^{1}$ and Giuseppe Satta ${ }^{2}$ \\ ${ }^{1}$ Istituto di Microbiologia, Università di Verona, 37134 Verona, Italy \\ ${ }^{2}$ Istituto di Microbiologia, Università Cattolica del Sacro Cuore, Roma, Italy
}

(Received 20 January 1993; revised 17 June 1993; accepted 24 June 1993)

\begin{abstract}
A series of thermosensitive cell growth mutants of Enterococcus hirae have been isolated. Most of these mutants elongate and some show reduced autolytic activity when incubated at the non-permissive temperature $\left(42{ }^{\circ} \mathrm{C}\right)$ in comparison to the wild-type incubated at the same temperature. When mutants were incubated for longer than $15 \mathrm{~min}$ at $42{ }^{\circ} \mathrm{C}$ and were then shifted to $30^{\circ} \mathrm{C}$, a lag proportional to the time of preincubation at $42{ }^{\circ} \mathrm{C}$ was observed before division, indicating that a certain time is necessary to restore normal levels of an active molecule(s) needed for septum formation and division. The addition of wild-type muramidase-1 permitted the immediate formation of septa and a single cell division; further addition of the enzyme stimulated the cells to divide once again. The other $E$. hirae autolytic enzyme, peptidoglycan-hydrolase-2, which is found in the culture medium, seemed to be involved in separation of daughter cells but may also take over the function of muramidase-1. A key role of both enzymes in septum formation and division is postulated.
\end{abstract}

\section{Introduction}

Over the past few years, studies on the role of penicillinbinding proteins (PBPs) in cell physiology and on the effect of $\beta$-lactam antibiotics which specifically inhibit septum formation, have demonstrated that a number of bacteria are capable of elongating when septum formation is inhibited (Fontana et al., 1983; Spratt, 1975). These observations are consistent with a model which proposes the existence in rods and some cocci of two different sites for cell wall growth whose activities are balanced under normal conditions (Satta et al., 1979). Inhibition of the activity of one of these sites implies the prevalence of the other, giving rise to filaments when septum formation is inhibited, or to coccoid cells if elongation of lateral wall is blocked (Lleò et al., 1990; Satta et al., 1983).

Isolation of thermosensitive (ts) cell growth mutants with one or more defects in septum formation at nonpermissive temperatures could provide an excellent system for studying the mechanism of cell wall growth in

\footnotetext{
*Author for correspondence. Tel. +3945 584606; fax +3945 584606.

Abbreviations: ts, temperature sensitive; Pg, peptidoglycan; SDSwalls, sodium dodecyl sulphate-treated cell walls; PBP, penicillinbinding protein.
}

those Gram-positive cocci, such as streptococci, which, according to the model, have two sites for cell wall assembly (Lleò et al., 1990).

In this study Enterococcus hirae ts cell growth mutants, which elongate after shifting the cultures to the nonpermissive condition, have been characterized. Since some of the elongating mutants showed reduced autolytic activity, with respect to wild-type, when incubated at $42{ }^{\circ} \mathrm{C}$, we considered the possibility that alterations in these enzymes could be the cause of the blockage of cell division in the mutants in the non-permissive condition, as has been previously suggested (Daneo-Moore \& Shockman, 1977; Fan \& Beckman, 1971; Fan et al., 1972; Tomasz \& Waks, 1975; Koch \& Burdett, 1986).

$E$. hirae contains two endogenous autolytic enzymes, both of which hydrolyse only the $\beta-1,4$ link between $N$ acetylmuramic acid and $N$-acetylglucosamine (Barrett $e t$ al., 1984b; Barrett \& Shockman, 1984). One enzyme, muramidase-1, is synthesized in a latent form (130 kDa) which is transported to specific sites in the cell wall where it is then activated, generating the active form $(87 \mathrm{kDa})$. Muramidase- 1 is active on $E$. hirae walls inactivated by sodium dodecyl sulphate (SDS-walls) (Barrett et al., 1984a; Shockman \& Barrett, 1983). The second enzyme, peptidoglycan-hydrolase-2 (Pg-hydrolase-2), comprising two proteins ( 125 and $75 \mathrm{kDa}$ ), is active on Micrococcus luteus SDS-walls and on purified Pg of E. hirae and is 


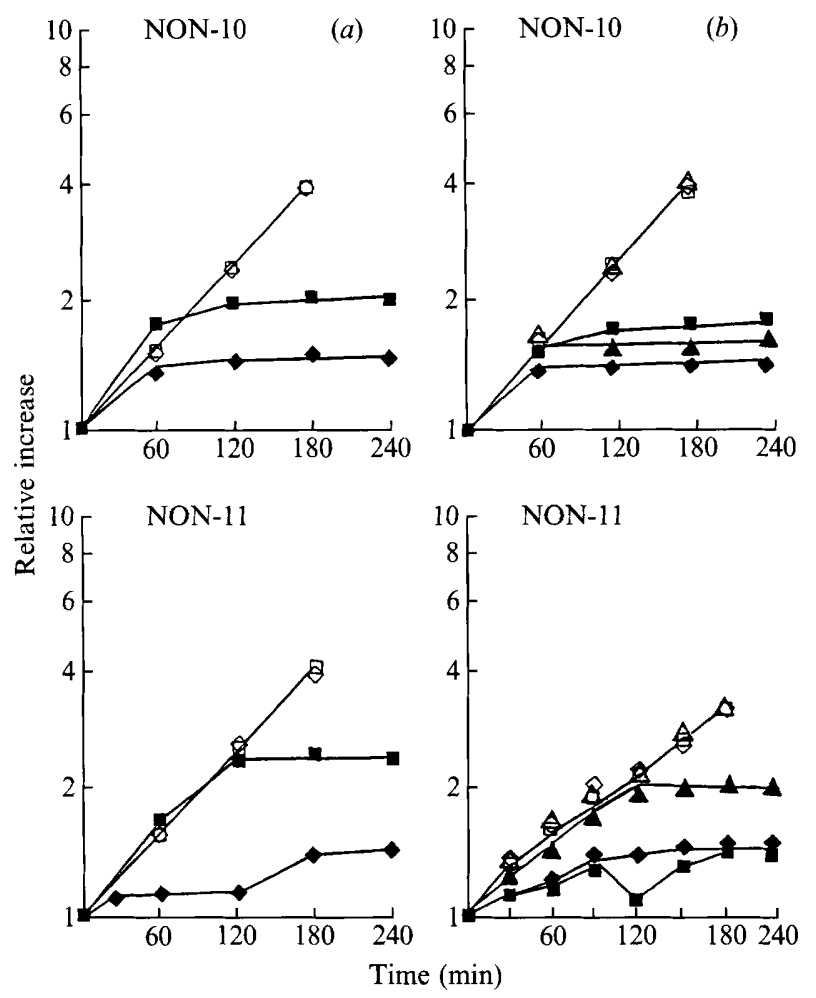

Fig. 1. (a) Cell number $(\diamond, \diamond)$ and mass $(\square, \boldsymbol{\square})$ increase at $30^{\circ} \mathrm{C}$ (open symbols) and at $42{ }^{\circ} \mathrm{C}$ (filled symbols) of a ts cell-growth mutant that retains coccal morphology $(\mathrm{NON}-10)$ and of one that elongates $(\mathrm{NON}-11)$ at $42^{\circ} \mathrm{C} .(b)$ DNA $(\diamond, \diamond)$, protein $(\triangle, \Delta)$ and peptidoglycan $(\square, \boldsymbol{\square})$ synthesis at $30^{\circ} \mathrm{C}$ (open symbols) and at $42{ }^{\circ} \mathrm{C}$ (filled symbols) of the same mutants. At time 0 the absolute values were: NON-10: $1.8 \times 10^{7}$ cells ml ${ }^{-1}$ at an $\mathrm{OD}_{650}$ of 0.1 , and 3930 c.p.m. $\mathrm{ml}^{-1}$ (DNA), 4290 c.p.m. ml ${ }^{-1}$ (proteins) and 2725 c.p.m. ml ${ }^{-1}$ (peptidoglycan). NON-11; $1.4 \times 10^{7}$ cells ml $^{-1}$ at an $\mathrm{OD}_{650}$ of $0 \cdot 1$, and 3650 c.p.m. $\mathrm{ml}^{-1}$ (DNA), 4180 c.p.m. $\mathrm{ml}^{-1}$ (proteins) and 2940 c.p.m. $\mathrm{ml}^{-1}$ (peptidoglycan). The data are from an experiment that was repeated twice with no significant differences.

found in the culture medium during growth (Kawamura \& Shockman, 1983b).

Preliminary experiments performed to study the recovery of division in some of the mutants in the presence of culture medium in which the wild-type had been grown permitted the identification of a factor allowing division at $42^{\circ} \mathrm{C}$ (Lleò et al., 1984, 1990). This compound also showed a lytic activity on SDS-walls of $E$. hirae and $M$. luteus. The effect of wild-type purified muramidase-1 and Pg-hydrolase- 2 on cell division of the mutants incubated at the non-permissive temperature was also studied.

\section{Methods}

Bacterial strains and growth conditions. Enterococcus hirae ATCC 9790 and 13 thermosensitive cell growth mutants derived from it were used in this study (see Tables 1 and 2). Bacterial strains were grown in Brain Heart Infusion broth (BHI, Difco) at $30^{\circ} \mathrm{C}$ or $42^{\circ} \mathrm{C}$. Growth was measured as $\mathrm{OD}_{650}$ in a Beckman DU6 spectrophotometer. Cell numbers were determined with a Coulter counter model ZBI equipped with a $30 \mu \mathrm{m}$ orifice, as previously described (Canepari et al., 1984b).

Selection procedure. An exponential phase culture of $E$. hirae was mutagenized with ethylmethanesulphonate (EMS) as described by Lleò et al. (1990). Briefly, exponentially growing cells were incubated with EMS at $30^{\circ} \mathrm{C}$ for $60 \mathrm{~min}$. Then cells were washed twice in $10 \mathrm{~mm}-$ phosphate buffer $(\mathrm{pH} 7)$ and incubated overnight in $\mathrm{BHI}$ at $30^{\circ} \mathrm{C}$. Penicillin enrichment, which is usually used to increase mutant selection, was avoided in this case in order to obtain that part of the population capable of changing their morphology. The mutagenized culture was plated on BHI agar, and plates were replicated and incubated at 30 and $42^{\circ} \mathrm{C}$. Clones which formed colonies at $30^{\circ} \mathrm{C}$ but not at $42^{\circ} \mathrm{C}$ were considered to be thermosensitive cell growth mutants.

Morphological examinations. Slides for microscopic examination and micrographs were prepared as described by Canepari et al. (1984a) and examined with a Leitz Orthoplan microscope equipped with an automatic camera.

Macromolecular synthesis. DNA, protein and Pg syntheses were determined by continuous incorporation of specific radiolabelled precursors (respectively $\left[{ }^{3} \mathrm{H}\right]$ thymidine, $2 \mu \mathrm{Ci} \quad(74 \mathrm{kBq}) \quad \mathrm{ml}^{-1}$; $\left[{ }^{3} \mathrm{H}\right]$ leucine, $2 \mu \mathrm{Ci} \mathrm{m} l^{-1}$ and $\left.\left[{ }^{3} \mathrm{H}\right] \mathrm{lysine}, 6 \mu \mathrm{Ci} \mathrm{ml}^{-1}\right)$ into trichloroaceticacid-precipitable fractions. Briefly, cells were grown at $30^{\circ} \mathrm{C}$ for at least three generations in the presence of radiolabelled precursors and then (when $\mathrm{OD}_{650}=0 \cdot 1$ ) the culture was subdivided into two parts. One was reincubated at $30^{\circ} \mathrm{C}$ and the other was shifted to $42^{\circ} \mathrm{C}$. At $30 \mathrm{~min}$ intervals, $1 \mathrm{ml} \mathrm{samples} \mathrm{were} \mathrm{taken,} \mathrm{precipitated} \mathrm{with} 5 \mathrm{ml}$ ice-cold $10 \%$ $(\mathrm{w} / \mathrm{v})$ trichloroacetic acid and maintained for $30 \mathrm{~min}$ on ice. The precipitated material was collected on $0.45 \mu \mathrm{m}$ filters and radioactivity was then measured in a Beckman LS 7000 counter. Before measuring radioactivity, samples for $\mathrm{Pg}$ synthesis were incubated with pronase to remove radioactivity bound to proteins, as described by Boothby $e t$ al . (1971).

Cellular autolysis. After incubation for $75 \mathrm{~min}$ at $42^{\circ} \mathrm{C}$, cells were rapidly collected by centrifugation, washed twice with ice-cold $0.01 \mathrm{M}$ phosphate buffer and resuspended in one-third of the original volume of $0.3 \mathrm{M}$-phosphate buffer ( $\mathrm{pH} 7)$. Samples were incubated at $30^{\circ} \mathrm{C}$ and $42^{\circ} \mathrm{C}$ and lysis was monitored turbidimetrically and expressed as percentage decrease in $\mathrm{OD}_{650}$.

Extraction and purification of autolytic enzymes. Muramidase- 1 was obtained from cell-wall autolysates as described by Shockman et al. (1967). Purification of enzyme was performed by affinity chromatography (Kawamura \& Shockman, 1983a). Pg-hydrolase-2 was obtained from culture supernatants and purified by binding these supernatants to SDS-inactivated walls of $M$. luteus as described by Kawamura \& Shockman $(1983 b)$. Enzymes were renaturated before use (Hager \& Burgess, 1980).

Assay for autolytic enzyme activity. Activity of muramidase- 1 and of Pg-hydrolase-2 was measured by the rate of dissolution of SDS-walls of $E$. hirae or $M$. luteus, respectively, in 10 mm-phosphate buffer, $\mathrm{pH} 7$, at $37^{\circ} \mathrm{C}$ (Cornett et al., 1978). SDS-walls were prepared by treatment of walls of $E$. hirae and $M$. luteus with $2 \%$ (w/v) SDS as described by Shockman et al. (1967). One unit of lytic activity corresponds to a $1 \%$ decrease in $\mathrm{OD}_{450}$ in $20 \mathrm{~min}$ at $37^{\circ} \mathrm{C}$.

Analysis of penicillin-binding proteins (PBPs). Analysis of PBPs was performed as previously described (Coyette et al., 1980). After binding with benzyl $\left[{ }^{14} \mathrm{C}\right]$ penicillin, membranes were solubilized with $2 \%$ SDS and proteins separated by SDS-PAGE (Laemmli, 1970). PBPs were visualized by fluorography.

Antibiotics and radiochemicals. Penicillin $\mathrm{G}$ was from Squibb. $\left[{ }^{3} \mathrm{H}\right]$ Thymidine [sp. act. $\left.20 \mathrm{Ci}(740 \mathrm{GBq}) \mathrm{mmol}^{-1}\right],\left[{ }^{3} \mathrm{H}\right]$ leucine [sp. act. 

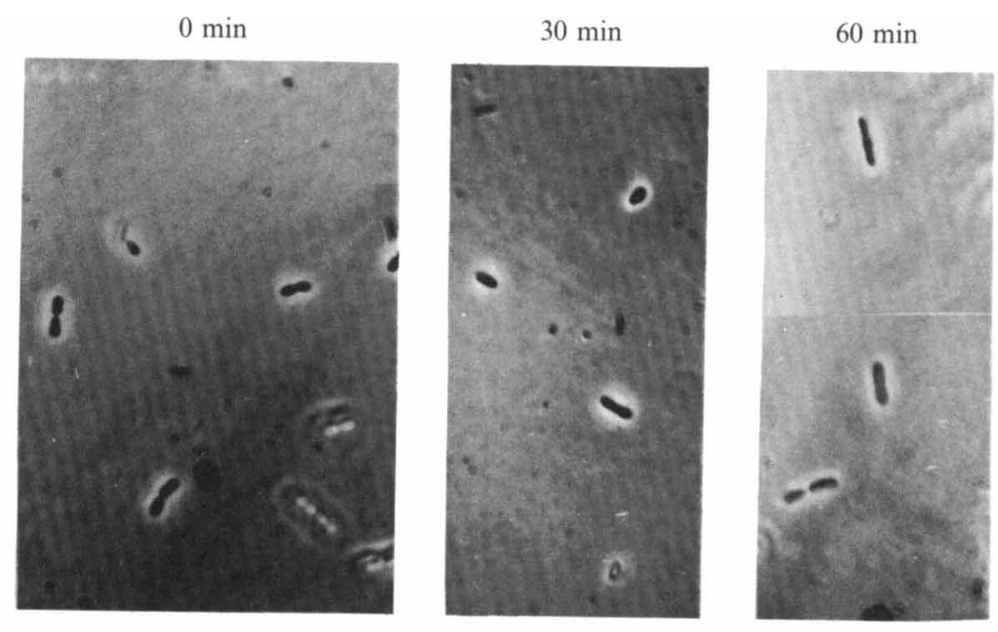

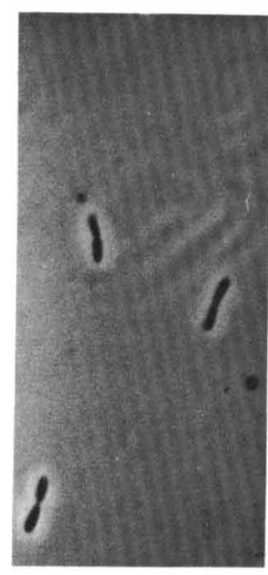

$90 \mathrm{~min}$

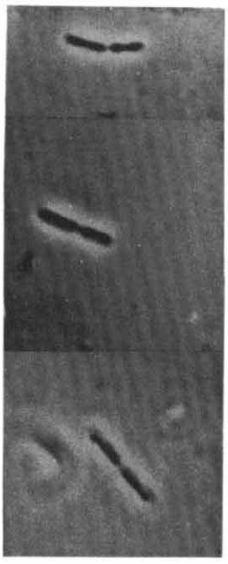

$120 \mathrm{~min}$

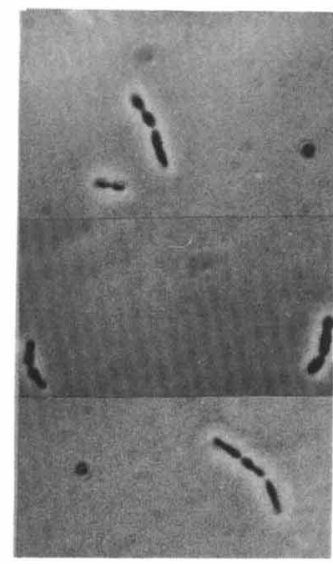

$150 \mathrm{~min}$

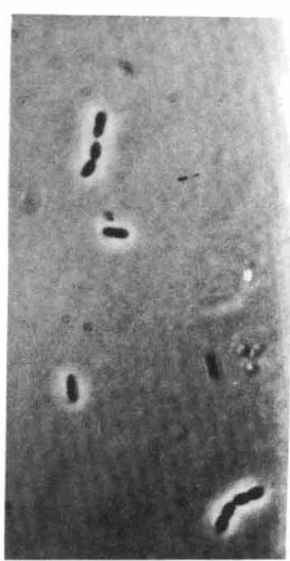

$180 \mathrm{~min}$

Fig. 2. Cell morphology of NON-11 ts cell growth mutant at different times during incubation at $42{ }^{\circ} \mathrm{C}$.

$\left.146 \mathrm{Ci}(5 \cdot 4 \mathrm{TBq}) \mathrm{mmol}^{-1}\right],\left[{ }^{3} \mathrm{H}\right] \mathrm{lysine}$ [sp. act. $\left.85 \mathrm{Ci}(3 \cdot 15 \mathrm{TBq}) \mathrm{mmol}^{-1}\right]$ and benzyl- $\left[{ }^{14} \mathrm{C}\right]$ penicillin [sp. act. $\left.54 \mathrm{mCi}(2 \cdot 0 \mathrm{GBq}) \mathrm{mmol}^{-1}\right]$ were from Amersham.

\section{Results}

\section{Morphological changes and cell division in mutants} incubated at $42^{\circ} \mathrm{C}$

A series (series NON) of ts cell growth mutants of $E$. hirae unable to form colonies at $42{ }^{\circ} \mathrm{C}$ has recently been isolated after mutagenesis with EMS and without selection with penicillin (Lleo et al., 1990). Of the 13 mutants used in this study, 10 elongated and 3 maintained coccal morphology when incubated at the non-permissive temperature $\left(42^{\circ} \mathrm{C}\right)$.

Fig. 1 shows the divisional behaviour of one (NON11) of the mutants which elongates when incubated at $42{ }^{\circ} \mathrm{C}$. All the other mutants that elongated at $42{ }^{\circ} \mathrm{C}$ showed similar behaviour with regard to morphology and division. A slight increase in cell number was observed over the first $15 \mathrm{~min}$ and then cell division stopped. After $15 \mathrm{~min}$, cells began to elongate (Fig. 2) reaching a maximum length in 60-90 min. Moreover, during elongation, the cell number remained constant, but cell mass increased about fivefold. Between 90 and 120 min of incubation at $42{ }^{\circ} \mathrm{C}$ apparently normal septa began to be formed, and after $150 \mathrm{~min}$ the septum formation was complete (Fig. 2). The cells formed (on average 3-4 cells per elongated element), each of which had a nucleus, could not separate or separated only partially (Fig. 2). A doubling or less of the cell number occurred. This is attributed to the growth of the organism in chains of unseparated cells; the Coulter counter underestimates cell numbers in such cases. Further divisions were not observed (Fig. 1).

In the case of NON-10 (and of the three strains retaining their coccal shape at the non-permissive temperature) cell number increased over $60 \mathrm{~min}$ of incubation at $42{ }^{\circ} \mathrm{C}$, after which no further divisions were observed (Fig. 1). 
Macromolecular synthesis in the mutants incubated at the non-permissive temperature

DNA, protein and $\mathrm{Pg}$ synthesis were measured in the mutants that elongate and in those that retain their coccal shape at $42^{\circ} \mathrm{C}$. As shown in Fig. 1, in a mutant (NON-11) which elongates at $42^{\circ} \mathrm{C}$, DNA and protein synthesis continued during elongation and then declined and stopped; $\mathrm{Pg}$ synthesis continued for at least 120-150 min. Table 1 shows the values of cell number increase and macromolecular synthesis of the mutants used in this study. It is also evident that the mutants show a wide variation in the pattern of macromolecular synthesis suggesting that the mutants may be disturbed in a number of quite different ways. In some of the elongating mutants (NON-11, NON-19, NON-39, NON-43, NON-48 and NON-76) we observed partial release of radioactivity bound to the cell wall polymer (which we will call Pg turnover) at the time corresponding to septum formation at $42{ }^{\circ} \mathrm{C}$ (Fig. 1 and Table 2). Although Pg continued to be synthesized after $120 \mathrm{~min}$ it appears to represent resynthesis of the Pg lost through degradation between 90 and $120 \mathrm{~min}$. In the mutant NON-10 and the other two mutants (Fig. 1 and Table 2) which maintained their coccal morphology at $42^{\circ} \mathrm{C}$, DNA and protein synthesis were inhibited immediately after the block of cell division, while $\mathrm{Pg}$ synthesis continued for some minutes after inhibition of cell division.

Evaluation of cell division and Pg synthesis in mutants grown at $30^{\circ} \mathrm{C}$ after different periods of incubation at the non-permissive temperature

In order to analyse whether a period of synthesis is required for cell division at the non-permissive temperature, or whether the material synthesized at $42^{\circ} \mathrm{C}$ may need to be held for some time at $30^{\circ} \mathrm{C}$ for its expression, as has been demonstrated for ts mutants of Esch. coli and other Gram-negative rods (Ahmed \& Rowbury, 1971; Reeve \& Clark, 1972), mutants were incubated at $42{ }^{\circ} \mathrm{C}$ for different periods of time before shifting the cultures to the permissive temperature.

Fig. 3(a) shows that if mutant NON-11 was incubated at $42{ }^{\circ} \mathrm{C}$ for less than $15 \mathrm{~min}$, cell division continued normally after the shift to $30^{\circ} \mathrm{C}$ : elongation did not begin and cells maintained their normal coccal shape and their ability to divide. After incubation at $42{ }^{\circ} \mathrm{C}$ for longer than $15 \mathrm{~min}(30,45$ and $60 \mathrm{~min})$ cell division started at $30^{\circ} \mathrm{C}$ after a lag proportional to the time of preincubation at the non-permissive temperature (Fig. $3 a$ ). Moreover, if elongation had already begun at $42^{\circ} \mathrm{C}$, it continued after shifting to $30^{\circ} \mathrm{C}$ until reaching the maximum and only then did septa begin to be formed
Table 1. Morphology and increase in cell number and macromolecular synthesis after $3 \mathrm{~h}$ incubation at $42^{\circ} \mathrm{C}$ in elongating and non-elongating $E$. hirae ts cell growth mutants

Data are representative results of an experiment that was repeated twice with no significant differences.

\begin{tabular}{|c|c|c|c|c|c|}
\hline \multirow[b]{2}{*}{ Strain } & \multirow{2}{*}{$\begin{array}{c}\text { Morphology } \\
\text { at } 42^{\circ} \mathrm{C}\end{array}$} & \multirow{2}{*}{$\begin{array}{c}\text { Increase } \\
\text { in cell } \\
\text { number } \\
(\%)\end{array}$} & \multicolumn{3}{|c|}{$\begin{array}{l}\text { Percentage increase } \\
\text { in synthesis of: }\end{array}$} \\
\hline & & & DNA & Protein & $\mathrm{Pg}$ \\
\hline Wild-type & Coccus & 470 & 450 & 485 & 480 \\
\hline NON-5 & Coccus & 70 & 60 & 75 & 150 \\
\hline NON-9 & Coccus & 85 & 90 & 95 & 150 \\
\hline NON-10 & Coccus & 50 & 50 & 60 & 80 \\
\hline NON-11 & Rod & 40 & 50 & 100 & 50 \\
\hline NON-29 & Rod & 30 & 130 & 210 & 220 \\
\hline NON-39 & Rod & 40 & 110 & 220 & 210 \\
\hline NON-43 & Rod & 50 & 120 & 200 & 110 \\
\hline NON-44 & Rod & 80 & 170 & 185 & 120 \\
\hline NON-48 & Rod & 90 & 110 & 195 & 220 \\
\hline NON-56 & Rod & 20 & 54 & 130 & 440 \\
\hline NON-76 & Rod & 50 & 70 & 140 & 420 \\
\hline NON-90 & Rod & 35 & 95 & 140 & 250 \\
\hline
\end{tabular}

Table 2. Autolytic activity of whole cells from ts cell growth mutants of $E$. hirae

The data are from an experiment that was repeated three times with no significant differences.

\begin{tabular}{|c|c|c|c|c|c|}
\hline \multirow[b]{2}{*}{ Strain* } & \multicolumn{2}{|c|}{$\begin{array}{c}\text { Percentage } \\
\text { decrease in } \\
\mathrm{OD}_{450} \text { in } \\
90 \text { min at: }\end{array}$} & \multicolumn{2}{|c|}{$\begin{array}{l}\text { Ratio wild } \\
\text { type: mutant } \\
\text { autolytic } \\
\text { activity at: }\end{array}$} & \multirow{2}{*}{$\begin{array}{c}\mathrm{Pg} \\
\text { turnover } \dagger \\
\text { at } 42^{\circ} \mathrm{C}\end{array}$} \\
\hline & $30^{\circ} \mathrm{C}$ & $42^{\circ} \mathrm{C}$ & $30^{\circ} \mathrm{C}$ & $42^{\circ} \mathrm{C}$ & \\
\hline Wild-type & 45 & 61 & $1 \cdot 00$ & 1.00 & - \\
\hline NON-5 & 35 & 59 & 1.25 & 1.03 & - \\
\hline NON-9 & 40 & 51 & $1 \cdot 10$ & $1 \cdot 19$ & - \\
\hline NON-10 & 37 & 21 & $1 \cdot 20$ & $2 \cdot 90$ & - \\
\hline NON-11 & 32 & 9 & 1.45 & $6 \cdot 70$ & + \\
\hline NON-19 & 43 & 55 & 1.04 & $1 \cdot 30$ & + \\
\hline NON-29 & 31 & 61 & 1.45 & 1.00 & - \\
\hline NON-39 & 29 & 50 & $1 \cdot 50$ & $1 \cdot 22$ & + \\
\hline NON-43 & 36 & 36 & $1 \cdot 20$ & 1.70 & + \\
\hline NON-44 & 30 & 61 & 1.55 & 1.00 & - \\
\hline NON-48 & 38 & 21 & 1.20 & $3 \cdot 00$ & + \\
\hline NON-56 & 29 & 60 & 1.55 & 1.01 & - \\
\hline NON-76 & 32 & 40 & 1.45 & 1.52 & + \\
\hline NON-90 & 39 & 66 & $1 \cdot 16$ & 0.92 & - \\
\hline
\end{tabular}

${ }^{*}$ Morphology of strains after $75 \mathrm{~min}$ incubation at $42{ }^{\circ} \mathrm{C}$ : $E$. hirae wild-type, NON-5, NON-9 and NON-10 were cocci; all other strains were rods.

$\dagger \mathrm{Pg}$ turnover indicates the release of radioactivity bound to $\mathrm{Pg}$ at $42^{\circ} \mathrm{C}$ between 90 and $120 \mathrm{~min}$, corresponding to the time of septum formation shown in Figs 1 and 2.

and division occurred. On the contrary, the mutants that did not elongate at $42^{\circ} \mathrm{C}$, divided 15 min after the shift to $30^{\circ} \mathrm{C}$ regardless of the length of preincubation at $42{ }^{\circ} \mathrm{C}$ (Fig. $3 b$ ). 

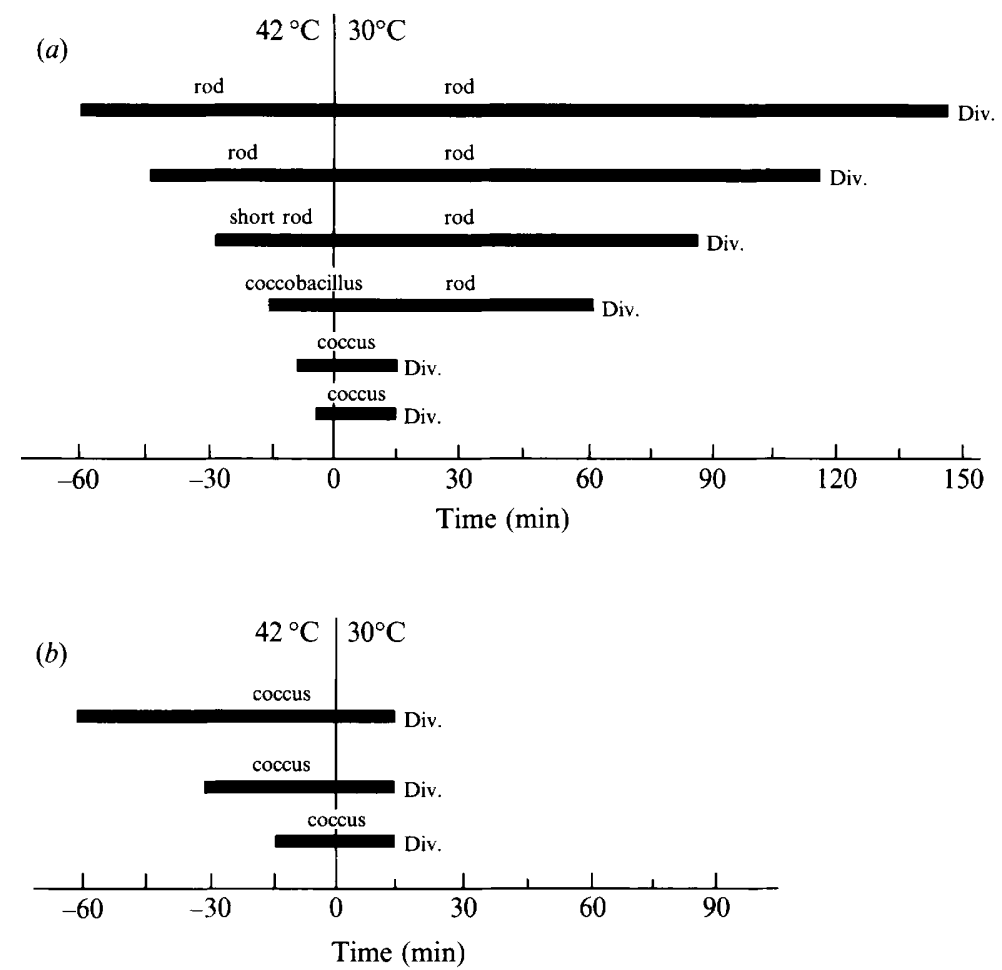

Fig. 3. Cell morphology and regrowth at $30^{\circ} \mathrm{C}$ of NON-11 (a) and NON-10 (b) mutants after different periods of incubation at $42^{\circ} \mathrm{C}$. Div., cell division.

$\mathrm{Pg}$ synthesis was evaluated during regrowth at $30^{\circ} \mathrm{C}$ after periods of $15,30,45$ and $60 \mathrm{~min}$ of incubation at $42{ }^{\circ} \mathrm{C}$ in mutants such as NON-11 that elongated at the non-permissive temperature. Degradation (turnover) of the wall polymer was observed. It should be noted that about half the cell wall synthesized is degraded (Fig. $4 b, c, d)$. The duration and intensity of this turnover were proportional to the time the mutants were held at the non-permissive temperature and it is also apparent that degradation became progressively slower with increasing periods at $42^{\circ} \mathrm{C}$ (Fig. $4 a-d$ ). $\mathrm{Pg}$ synthesis continued normally at the end of the turnover and cell division always started $30 \mathrm{~min}$ after that time. $\mathrm{Pg}$ synthesis started immediately after the shift to $30^{\circ} \mathrm{C}$ when NON-10 and the other mutants that did not elongate at $42^{\circ} \mathrm{C}$ were analysed (Fig. $4 e, f$ ).

\section{Analysis of penicillin-binding proteins}

The PBPs of all 13 mutants used in this study were analysed, but no alterations of the electrophoretic PBP patterns were observed (data not shown).

\section{Autolytic activity in ts cell-growth mutants during incubation at the non-permissive temperature}

Table 2 shows that cellular autolysis tested at the nonpermissive temperature was significantly decreased in some of the mutants compared to wild-type E. hirae grown at the same temperature. These data suggested that, at least in some of the mutants, an alteration of the autolytic enzymes might be correlated with inhibition of septum formation and with the inability of the cells to separate when the septa were complete. There was also a correlation in the elongating mutants but not in those conserving their coccal shape, between reduced autolytic activity and peptidoglycan turnover at $42{ }^{\circ} \mathrm{C}$ (Table 2).

Table 3 presents the values of muramidase- 1 activity from the wild-type and a ts cell-growth mutant (NON11) grown at $42{ }^{\circ} \mathrm{C}$; muramidase- 1 showed at least a fiveto sixfold reduction in the mutant compared to the wildtype, while values were similar when both strains were grown at $30^{\circ} \mathrm{C}$. Marked differences in the susceptibility to muramidase- 1 of the walls from the mutant NON-11 and from the parent were also observed. Similar, but small differences, were found with muramidase- 1 extracted from cells grown at $42{ }^{\circ} \mathrm{C}$. The data in Table 4 demonstrate that the activity of Pg-hydrolase-2 (when tested on SDS-walls of $M$. luteus) was also reduced by about half in the mutant grown at $42{ }^{\circ} \mathrm{C}$ compared to the wild-type grown at the same temperature.

\section{Effect of purified muramidase-1 and Pg-hydrolase-2}

from wild-type on cell division of ts cell-growth mutants incubated at $42^{\circ} \mathrm{C}$

Muramidase-1 and Pg-hydrolase-2 were purified as described in Methods. Electrophoresis on SDSpolyacrylamide gel revealed a single band at $87 \mathrm{kDa}$ corresponding to the active form of muramidase- 1 and 


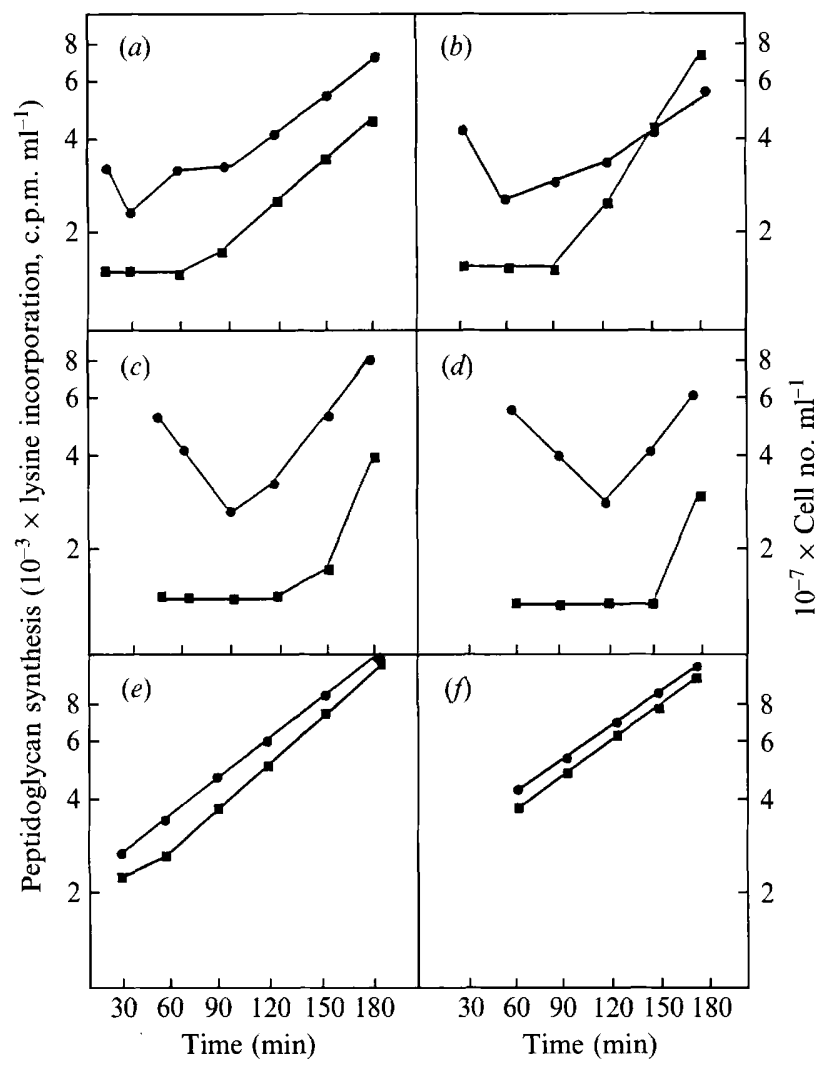

Fig. 4. Cell number $(\boldsymbol{\square})$ and peptidoglycan synthesis $(\boldsymbol{)})$ increases at $30^{\circ} \mathrm{C}$ of NON-11 mutant after $15(a), 30(b), 45(c)$ and $60(d)$ of incubation at $42^{\circ} \mathrm{C}$ and of NON-10 mutant after $30(e)$ and $60(f)$ min of incubation at $42{ }^{\circ} \mathrm{C}$. The data are from an experiment that was repeated twice with no significant differences. The experiment was also done with three other mutants with similar results.

Table 3. Enzymic activity of muramidase-1 from wildtype and from a ts cell growth mutant $(N O N-11)$ on $S D S$-walls of both wild-type and the same mutant

Both wild type and NON-11 were incubated at $42{ }^{\circ} \mathrm{C}$ for $75 \mathrm{~min}$ before SDS-walls preparation. It is important to note that the wild-type had a higher growth rate at $42{ }^{\circ} \mathrm{C}$ than at $30^{\circ} \mathrm{C}$ (Fontana et al., 1983). Activity is expressed as units of lytic activity at $37^{\circ} \mathrm{C}(\mathrm{mg} \text { protein })^{-1}$. One unit of lytic activity corresponds to a $1 \%$ decrease in $\mathrm{OD}_{450}$ in $20 \mathrm{~min}$ at $37^{\circ} \mathrm{C}$. The data are from an experiment that was repeated four times with no significant differences.

\begin{tabular}{|c|c|c|c|c|}
\hline \multirow[b]{3}{*}{ Muramidase-1 from: } & \multicolumn{4}{|c|}{ SDS-walls of: } \\
\hline & \multicolumn{2}{|c|}{$\begin{array}{l}E \text {. hirae } \\
\text { grown at: }\end{array}$} & \multicolumn{2}{|c|}{$\begin{array}{l}\text { NON-11 } \\
\text { grown at: }\end{array}$} \\
\hline & $30^{\circ} \mathrm{C}$ & $42^{\circ} \mathrm{C}$ & $30^{\circ} \mathrm{C}$ & $42^{\circ} \mathrm{C}$ \\
\hline Wild-type grown at $30^{\circ} \mathrm{C}$ & 83 & 83 & 584 & 280 \\
\hline NON-11 grown at $30^{\circ} \mathrm{C}$ & 57 & 98 & 771 & 340 \\
\hline Wild-type grown at $42^{\circ} \mathrm{C}$ & 866 & 1068 & 2533 & 1723 \\
\hline NON-11 grown at $42^{\circ} \mathrm{C}$ & 133 & 200 & 650 & 525 \\
\hline
\end{tabular}

Table 4. Enzymic activity of Pg-hydrolase-2 from wildtype and from a ts cell growth mutant $(N O N-11)$ on $S D S$-walls of both $E$. hirae and M. luteus

Activity is expressed as units of lytic activity at $37^{\circ} \mathrm{C}(\mathrm{mg}$ protein $)^{-1}$. One unit of lytic activity corresponds to a $1 \%$ decrease in $\mathrm{OD}_{450}$ in $20 \mathrm{~min}$ at $37^{\circ} \mathrm{C}$. The data are from an experiment that was repeated three times with no significant differences.

\begin{tabular}{ccc}
\hline \hline & \multicolumn{2}{c}{ SDS-walls of: } \\
\cline { 2 - 3 } Pg-hydrolase-2 from: & E. hirae & M. luteus \\
\hline Wild-type grown at $30^{\circ} \mathrm{C}$ & 36 & 750 \\
NON-11 grown at $30^{\circ} \mathrm{C}$ & 40 & 735 \\
Wild-type grown at $42^{\circ} \mathrm{C}$ & 70 & 990 \\
NON-11 grown at $42^{\circ} \mathrm{C}$ & 23 & 501 \\
\hline
\end{tabular}
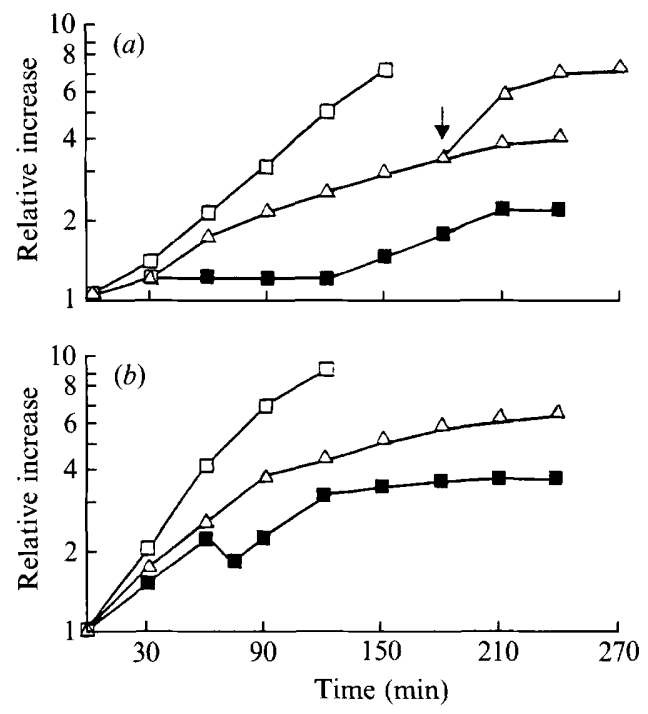

Fig. 5. Cell number $(a)$ and peptidoglycan synthesis $(b)$ increases of a ts cell-growth mutant (NON-11) incubated at $30^{\circ} \mathrm{C}(\square)$, at $42{ }^{\circ} \mathrm{C}(\boldsymbol{\square})$ and at $42{ }^{\circ} \mathrm{C}$ in the presence of one unit of muramidase-1 $(\triangle)$. The arrow indicates the addition of a second equal dose of the same

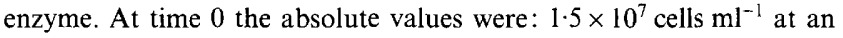
$\mathrm{OD}_{650}$ of 0.11 , and 2105 c.p.m. $\mathrm{m}^{-1}$ for peptidoglycan synthesis. The results are from an experiment that was repeated four times using different enzyme preparations. The experiment was also done with three other mutants with similar results.

two bands at 123 and $75 \mathrm{kDa}$ corresponding to $\mathrm{Pg}$ hydrolase-2 (data not shown).

When purified enzymes were added to cultures of the mutants and immediately incubated at $42{ }^{\circ} \mathrm{C}$, complete inhibition of cell elongation was observed when muramidase-1 was tested, while only partial inhibition of elongation was observed when Pg-hydrolase- 2 was added (data not shown). In both cases, at least $100 \%$ increases in cell number and in Pg synthesis (Fig. 5) were observed in the NON-11 culture compared to the control without enzymes. The best stimulatory activity of both enzymes was obtained with about $0.01 \mu \mathrm{g}$ enzyme $\left(10^{8} \text { cells }\right)^{-1}$ for 
muramidase- 1 and $0.02 \mu \mathrm{g}$ enzyme $\left(10^{8} \text { cells }\right)^{-1}$ for Pghydrolase- 2 corresponding approximately to the physiological amounts of these enzymes in the wild-type (Kawamura \& Shockman, 1983a,b). These amounts of enzymes did not cause any lytic effect on cell cultures, as reported by Tomasz \& Waks (1975) and Fan \& Beckman (1971). When chloramphenicol at $10 \mu \mathrm{g} \mathrm{ml}^{-1}$ (the minimal concentration inhibiting protein synthesis) was added together with muramidase-1 during a shift to $42{ }^{\circ} \mathrm{C}$, no changes in shape or in cell division were observed (data not shown) suggesting that active protein synthesis was needed.

When, after doubling of the cell number, a further dose of enzyme was added, a further $100-150 \%$ increase in cell number and $\mathrm{Pg}$ synthesis was observed. In addition, when each of the two enzymes was added to the culture incubated at $42{ }^{\circ} \mathrm{C}$, the decrease in Pg synthesis occurring at $90 \mathrm{~min}$ was not observed (Fig. 5).

If autolytic enzymes were added to the cultures after 90 min of incubation at $42{ }^{\circ} \mathrm{C}$, when cells were already elongated, separation of daughter cells was observed with a consequent increase in cell number higher than that shown by control cultures incubated without enzymes. Moreover, when a NON-11 culture with added autolytic enzymes was maintained for $45 \mathrm{~min}$ at $42{ }^{\circ} \mathrm{C}$ and then shifted to $30^{\circ} \mathrm{C}$, cell division started immediately, while control culture without enzymes showed a $120 \mathrm{~min}$ lag before cell division. Again, addition of chloramphenicol inhibited recovery of cell division, thus indicating that de novo protein synthesis was needed.

\section{Discussion}

We have previously demonstrated that in coccoid bacteria two distinct biochemical reactions that we call 'sites', responsible for lateral wall extension and septation, may exist for peptidoglycan assembly but that cells present a coccal morphology because the septum formation site always prevails over the lateral wall elongation site (Lleò et al., 1990). When septum formation is inhibited, elongation may be expressed so that some cocci change to rods. In this study, we have demonstrated the validity of this hypothesis in a number of ts cell-growth mutants of $E$. hirae which elongate when incubated in the non-permissive condition. Even if these mutants are capable of forming a series of septa on continuous incubation at $42{ }^{\circ} \mathrm{C}$, cells separate only partially and further septum formation and division do not occur.

Analysis of macromolecular synthesis in E. hirae mutants which elongate and in those retaining their coccal morphology at $42^{\circ} \mathrm{C}$ confirm our previous hypothesis that the envelope controls the increase in cell mass, so that when the envelope is able to extend, new macromolecules can be synthesized (mutants elongating at $42{ }^{\circ} \mathrm{C}$ ), but when the extension of the envelope is inhibited, macromolecular synthesis is also blocked as no available space is created (mutants retaining coccal morphology) (Lleò et al., 1990).

Since septum formation is a complex event in the cell cycle requiring different genetically controlled steps (Ishino et al., 1989), a mutation causing the block of septum formation may affect one or more of the different proteins involved in this process. As has been previously postulated, at least one PBP is directly involved in septum formation in E. hirae (Coyette et al., 1980; Pucci et al., 1986; Canepari et al., 1987). A mutation in this protein could cause the inhibition of septum formation, as has been clearly demonstrated in other bacteria (Ishino \& Matshuashi, 1981; Spratt, 1977). Nevertheless, no apparent defect in PBP patterns was observed in any of the 13 ts cell-growth mutants isolated from $E$. hirae and analysed here.

On the contrary, analysis of autolytic activity revealed a reduction in such activity in some of the mutants when grown at the non-permissive temperature. As autolytic enzymes seem to be necessary for septum formation and cellular separation (Daneo-Moore \& Shockman, 1977), a defect in these proteins may interfere with septation. Among the elongating mutants which show a reduced autolytic activity we chose mutant NON-11 for further studies because of its more marked reduction in activity. Data presented (Table 3) show that cell walls of NON-11 are more sensitive to muramidase- 1 activity than cell walls of wild-type. This fact could (in part) explain the reduced amount of the enzyme present in the mutant. However, only definition of the chemical composition of the $\mathrm{Pg}$ will clarify whether the reduced amount of muramidase- 1 is the primary defect of the mutant or a consequence of the different chemical composition of its walls.

The regrowth of NON-11 after different periods of incubation at $42{ }^{\circ} \mathrm{C}$ demonstrated the need for the completion of elongation before septa can be initiated, as previously suggested (Satta et al., 1983), and indicates involvement of ts defects in one or more molecules needed for cell division, as is the case with Esch. coli BUG-6 (Reeve \& Clark, 1972) and other strains (Ahmed \& Rowbury, 1971). Longer periods of incubation at $42{ }^{\circ} \mathrm{C}$ caused longer delays in initiation of division at $30^{\circ} \mathrm{C}$, indicating that longer times are needed to restore normal levels of the active molecule(s) for septum formation and division. These data are very similar to those on recovery of autolytic activity of $E$. hirae cells from starvation (Pooley \& Shockman, 1969).

Probably because the defective molecule(s) is synthesized at $42{ }^{\circ} \mathrm{C}$ in an altered form, the longer the incubation at the non-permissive temperature the higher 
will be the proportion of defective molecules compared to the active form and the longer will be the time necessary to restore normal levels of the functional molecules at $30^{\circ} \mathrm{C}$. Only when these levels are raised, do cells begin to form septa and divide. It is suggested that this molecule(s) may be an autolytic enzyme whose role in septum formation has often been postulated (DaneoMoore \& Shockman, 1977; Pooley et al., 1972; Shockman et al., 1974), but never demonstrated.

Pg turnover was observed during regrowth and was proportional to the time of preincubation of the cultures at $42{ }^{\circ} \mathrm{C}$. Turnover (the massive release of radioactivity from $\mathrm{Pg}$ during its synthesis) was also observed in some strains when Pg synthesis was analysed at the time of septum formation at $42^{\circ} \mathrm{C}$. However, the rate of turnover was not measured directly. Although $\mathrm{Pg}$ turnover has never been described in E. hirae (Boothby et al., 1973), we observed a turnover of wall material in the wild-type when cells were grown in a rich medium (BHI) but not in the chemically defined medium used by others (Boothby et al., 1973) (data not shown).

This $\mathrm{Pg}$ turnover occurring during regrowth at $30{ }^{\circ} \mathrm{C}$ and before cell division also suggests involvement of a lytic enzyme as the cause of alterations in the mutants. We suggest that this turnover, whose duration is proportional to the time the cultures are held at $42^{\circ} \mathrm{C}$, may represent a rearrangement of the cell wall in order to localize the new sites for septum initiation in an elongated bacterium. Similarly, the same explanation may be given for the turnover observed in rods at $42^{\circ} \mathrm{C}$ between 90 and $120 \mathrm{~min}$ when it is needed to localize the new sites for septum formation. Moreover, there is a good correlation between reduced autolytic activity (compared to the wild-type) and Pg turnover at the time of septation in the case of rod-shaped mutants, while mutants which retain coccal morphology never exhibit Pg turnover during the cell cycle at $42^{\circ} \mathrm{C}$ (see Table 2 ).

We suggest that these $E$. hirae mutants are defective in septum formation and that, at least in some of the mutants examined, the molecule(s) involved in the cell division alteration may be autolytic enzymes whose activity is reduced at the non-permissive temperature. Thermosensitivity of the enzymes at $42^{\circ} \mathrm{C}$ has not been observed (unpublished observations), thus suggesting that synthesis is reduced at the restrictive temperature.

This hypothesis is supported by several results obtained in this study. The addition of wild-type muramidase- 1 to the NON-11 mutant permitted the immediate formation of septa and a single division of the cells. In this case no turnover was observed because the cell maintained its normal morphology (coccus) and septa were formed at the due time as in the control. Further additions of the enzyme stimulated the cells to divide again. Similarly, the recovery of the different autolysin functions in deficient mutants was observed when exogenous enzyme was added to cell cultures (Fan \& Beckman, 1971; Tomasz \& Waks, 1975; Koch \& Burdett, 1986). If, on the other hand, the enzyme was added when cells had already begun to elongate, no immediate effects were observed and only when cells were completely elongated, did septa form and division occur. This provides further support for our hypothesis that elongation and septation are two alternating processes (Satta et al., 1980).

Similarly, when the mutants were incubated briefly at the non-permissive temperature in the presence of the autolytic enzyme, the return to the permissive condition caused the immediate division of the cells. On the contrary, when preincubation at $42^{\circ} \mathrm{C}$ was done without enzyme, a lag was observed before division, indicating that time at $30^{\circ} \mathrm{C}$ was needed before cells could synthesize a sufficient quantity of normal autolytic enzyme to form septa.

These data demonstrate the fundamental role of autolytic enzymes in septum formation. Pg-hydrolase-2, an enzyme which is not active on $E$. hirae walls, causes only partial inhibition of the elongation process, indicating that this enzyme may take over, albeit not completely, the function of muramidase-1. Unfortunately, to date it has not been possible to isolate mutants which completely lack the autolytic system, and thus it is very difficult to establish the precise role of each of the lytic enzymes in the cell cycle. However, we have seen that the cells which remain attached to one another forming chains in the control culture without enzyme can undergo separation when Pg-hydrolase- 2 is added, giving rise to a doubling of the cell number. Although muramidase- 1 may also stimulate this separation, the fact that only Pg-hydrolase- 2 is found in the culture medium (Kawamura \& Shockman, 1983b) makes it more likely that the latter enzyme is mainly involved in the separation of the daughter cells, operating from the outside.

We thank Anthony Steele for editing the text and Maria Carla Tafi for her invaluable technical assistance. This study was supported by grant 92.00038.41 from National Research Council (CNR). Targeted Project 'Prevention and Control Disease Factors' (subproject 'Causes of Infectious Diseases').

\section{References}

AHMED, N. \& Rowbury, R. J. (1971). A temperature sensitive cell division component in a mutant of Salmonella typhimurium. Journal of General Microbiology 67, 107-115.

BarretT, J. F. \& Shockman, G. D. (1984). Isolation and characterization of soluble peptidoglycan from several strains of Streptococcus faecium. Journal of Bacteriology 159, 511-519.

Barrett, J. F., Dolinger, D. L., Schramm, V. L. \& Shockman, G. D. $(1984 a)$. The mechanism of soluble peptidoglycan hydrolysis by an autolytic muramidase. Journal of Biological Chemistry 259, 11818-11827. 
Barrett, J. F., Schramm, V. L. \& Shockman, G. D. (1984b). Hydrolysis of soluble, linear, un-cross-linked peptidoglycans by endogenous bacterial $\mathrm{N}$-acetylmuramoylhydrolases. Journal of Bacteriology 159, 520-526.

Boothby, D., Daneo-Moore, L. \& Shockman, G. D. (1971). A rapid, quantitative and selective estimation of radioactively labeled peptidoglycan in Gram-positive bacteria. Analytical Biochemistry 44, 645-653.

Boothby, D., Daneo-Moore, L., Higgins, M. L., Coyette, J. \& Shockman, G. D. (1973). Turnover of bacterial cell wall peptidoglycans. Journal of Biological Chemistry 248, 2161-2169.

CANEPARI, P., BotTA, G. \& SATTA, G. (1984a). Inhibition of lateral wall elongation by mecillinam stimulates cell division in certain cell division conditional mutants of Escherichia coli. Journal of Bacteriology 157, 130-133.

Canepari, P., Lleò, M. M., Fontana, R., Satta, G., Shockman, G. D. \& Daneo-MoORE, L. (1984b). Division of thermosensitive Streptococcus faecium mutants after return to permissive temperature. Journal of Bacteriology 160, 427-429.

Canepari, P., Lleò, M. M., Fontana, R. \& Satta, G. (1987). Streptococcus faecium mutants that are temperature sensitive for cell growth and show alterations in penicillin binding proteins. Journal of Bacteriology 169, 2432-2439.

Cornett, J. B., Redman, B. E. \& Shockman, G. D. (1978). Autolytic defective mutant of Streptococcus faecalis. Journal of Bacteriology 133, 631-640.

Coyette, J., Ghuysen, J. M. \& Fontana, R. (1980). The penicillin binding proteins in Streptococcus faecalis ATCC 9790. European Journal of Biochemistry 110, 445-456.

Daneo-Moore, L. \& Shockman, G. D. (1977). The bacterial cell surface in growth and division. In Cell Surface Reviews, vol. 4, pp. 597-715. Edited by G. Poste. Amsterdam: Elsevier/North Holland Biochemical Press.

Fan, D. P. \& Beckman, M. M. (1971). Mutant of Bacillus subtilis demonstrating the requirement of lysis for growth. Journal of Bacteriology 105, 629-636.

Fan, D. P., Beckman, M. M. \& Cunningham, W. P. (1972). Ultrastructural studies on a mutant of Bacillus subtilis whose growth is inhibited due to insufficient autolysin production. Journal of Bacteriology 109, 1247-1257.

Fontana, R., Canepari, P., Satta, G. \& Coyette, J. (1983). Streptococcus faecalis ATCC 9790 penicillin binding proteins and penicillin sensitivity are heavily influenced by growth conditions: proposal for an indirect mechanism of growth inhibition by betalactams. Journal of Bacteriology 154, 916-923.

HAGER, D. A. \& BURGESS, R. R. (1980). Elution of proteins from SDSpolyacrylamide gels, removal of SDS, and renaturation of enzymatic activity: results with sigma-subunit of Escherichia coli RNA polymerase, wheat germ DNA topoisomerase, and other enzymes. Analytical Biochemistry 109, 76-86.

Ishino, F. \& Matshuashi, M. (1981). Peptidoglycan synthetic enzyme activities of highly purified Penicillin binding protein 3 in Escherichia coli: a septum-forming reaction sequence. Biochemical and Biophysical Research Communications 101, 905-911.

Ishino, F., Jung, H. K., IKeda, M., DoI, M., WaChi, M. \& Matshuashi, M. (1989). New mutations $\mathrm{fts}$-36, lts-33, and $\mathrm{fts} W$ clustered in the mra region of the Escherichia coli chromosome induce thermosensitive cell growth and division. Journal of Bacteriology 171, 5523-5530.

Kawamura, T. \& Shockman, G. D. (1983a). Purification and some properties of the endogenous autolytic $N$-acetylmuramoylhydrolase of Streptococcus faecium, a bacterial glycoenzyme. Journal of Biological Chemistry 258, 9514-9521.
Kawamura, T. \& Shockman, G. D. (1983b). Evidence for the presence of a second peptidoglycan hydrolase in Streptococcus faecium. FEMS Microbiology Letters 19, 65-69.

KocH, A. L. \& BURDETT, D. J. (1986). Normal pole formation during total inhibition of wall synthesis. Journal of General Microbiology 132, 3441-3449.

LAEMMLI, U. K. (1970). Cleavage of structural proteins during the assembly of the head of bacteriophage T4. Nature, London 227 , 680-685

Lleò, M. M., Canepari, P. \& Fontana, R. (1984). Recovery in the supernatant of wild type Streptococcus faecium culture of a cell division stimulating factor. EMBO Workshop on Regulation of the Cell Cycle in Prokaryotes, pp. III-32.

Lleò, M. M., Canepari, P. \& Satta, G. (1990). Bacterial cell shape regulation: testing of additional predictions unique to the two competing sites model for peptidoglycan assembly and isolation of conditional rod-shaped mutants from some wild cocci. Journal of Bacteriology 172, 3758-3771.

Pooley, H. M. \& Shockman, G. D. (1969). Relationship between the latent form and the active form of the autolytic enzyme of Streptococcus faecalis. Journal of Bacteriology 100, 617-624.

Pooley, H. M., Shockman, G. D., Higgins, M. L. \& Porres-Juan, J. (1972). Some properties of two autolytic-defective mutants of Streptococcus faecalis ATCC 9790. Journal of Bacteriology 109 , 423- 431.

Pucci, M. J., Hinks, E. T., Dicker, D. T., Higgins, M. L. \& DaneoMOORE, L. (1986). Inhibition by beta-lactam antibiotics at two different times in the cell cycle of Streptococcus faecium ATCC 9790. Journal of Bacteriology 165, 682-688.

ReEve, J. N. \& Clark, D. J. (1972). Cell division of Escherichia coli BUG-6: effect of varying the temperature used as the non-permissive growth condition. Journal of Bacteriology 110, 122-125.

Satta, G., Fontana, R., Canepari, P. \& Botta, G. (1979). Peptidoglycan synthesis in cocci and rods of a $\mathrm{pH}$-dependent morphologically conditional mutant of Klebsiella pneumoniae. Journal of Bacteriology 137, 727-734.

Satta, G., Canepari, P., Botta, G. \& Fontana, R. (1980). Control of cell septation by lateral wall extension in $\mathrm{pH}$-conditional morphology mutant of Klebsiella pneumoniae. Journal of Bacteriology 142, 43-51.

Satta, G., Canepari, P. \& Fontana, R. (1983). A novel hypothesis to explain regulation of the murein sacculus shape. In The Target of Penicillin, pp. 135-140. Berlin: Walter de Gruyter.

Shockman, G. D. \& Barrett, J. F. (1983). Structure, function and assembly of cell wall of Gram-positive bacteria. Annual Review of Microbiology 37, 501-527.

Shockman, G. D., Thompson, J. S. \& Conover, M. J. (1967). The autolytic enzyme system of Streptococcus faecalis. II. Partial characterization of the autolysins and its substrate. Biochemistry 6 , 1054-1065

Shockman, G. D., Daneo-Moore, L. \& Higgins, M. L. (1974). Problems of cell wall and membrane growth, enlargement and division. Annals of the New York Academy of Science 235, 161-197.

SPRATT, B. G. (1975). Distinct penicillin binding proteins involved in the division, elongation and cell shape of Escherichia coli K12. Proceedings of the National Academy of Sciences of the United States of America 72, 2999-3003.

SPRATT, B. G. (1977). Thermosensitive cell division mutants of Escherichia coli with thermolabile Penicillin binding proteins. Journal of Bacteriology 131, 293-305.

Tomasz, A. \& WAKs, S. (1975). Enzyme replacement in a bacterium: phenotypic correction by the experimental introduction of the wild type enzyme into a live enzyme defective mutant Pneumococcus. Biochemical and Biophysical Research Communications 65, 1311-1319. 